\title{
Thyrotropin secreting pituitary tumours: a cause of hyperthyroidism
}

\author{
IB RAHIM S SALTI, NUHA NUWA YRI-S ALTI, \\ RONALD A BERGMAN, SAMI I NASSAR, \\ K AMEL F MUAKKASAH AND ITAF FAKHRI-SAHLI
}

From the Departments of Internal Medicine, Human Morphology and Surgery, Faculty of Medicine, American University of Beirut, Beirut, Lebanon

SUMMARY Pituitary thyrotropin excess resulting in hyperthyroidism has been previously reported in only 25 patients, of whom 19 had a pituitary tumour. This report describes a patient in whom a thyrotropin-producing pituitary tumour was associated with triiodothyronine thyrotoxicosis. Hypophysectomy was followed by a prompt fall in serum thyrotropin and a return to a euthyroid state.

Excessive pituitary thyrotropin (TSH) secretion is one of the least common causes of hyperthyroidism. The 25 cases described so far can be classified in two groups (table). The first consists of 19 patients who had radiological evidence of sellar enlargement, necessitating hypophysectomy or pituitary irradiation or both. ${ }^{1-18}$ The second group consists of six patients who had no sellar enlargement. ${ }^{12}$ 19-22 $^{\text {This }}$ report describes a patient in whom excessive TSH production by a pituitary tumour resulted in triiodothyronine $\left(T_{3}\right)$ thyrotoxicosis. Previously reported cases of TSHinduced hyperthyroidism are reviewed.

\section{Case report}

A 31-year-old man first presented in 1970 , at the age of 24 years, with hyperthyroidism of two months duration, associated with a diffusely and symmetrically enlarged thyroid. Eye examination was normal but there is no record of the visual field examination. Thyroidal I ${ }^{131}$ uptake was $79 \%$ at four hours and $75 \%$ at 24 and 48 hours. Serum thyroxine $\left(T_{4}\right)$ was $87.5 \mathrm{nmol} / 1$ (normal range, 57.9-154). Although no direct measurement of serum $T_{3}$ was available then, the provisional diagnosis was $T_{3}$-thyrotoxicosis. Treat-

Address for reprint requests: Dr IS Salti, Department of Internal Medicine, American University of Beirut, Beirut, Lebanon.

Accepted 30 July 1980 ment with methimazole, $30 \mathrm{mg}$ per day, resulted in amelioration of the patient's symptoms but the goitre persisted. Treatment was continued for two years, but three months after its discontinuation the hyperthyroid state reappeared necessitating reinstitution of the same antithyroid regimen for an additional two years. In 1974, a subtotal thyroidectomy was performed at another hospital. Histopathological examination of the excised tissue was reported as thyroid hyperplasia.

Eighteen months after the thyroidectomy, the hyperthyroid state reappeared gradually. Physical examination in February 1977 revealed a regular pulse rate of $120 / \mathrm{min}$, a warm moist skin and a diffusely enlarged thyroid, about four times normal size. There was no exopthalmos or skin abnormality. There was a bitemporal visual field defect more pronounced on the left side. Serum $T_{4}$ was $70.8 \mathrm{nmol} / 1$ serum $T_{3}$ was $8.77 \mathrm{nmol} / 1$ (normal $1.08-2.92$ ) and $I^{131}$ uptake $81 \%$ at four hours and $82 \%$ at 24 hours. Serum TSH, determined by radioimmunoassay was $46 \mu \mathrm{U} / \mathrm{ml}$ (normal range, 2-8 $\mu \mathrm{U} / \mathrm{ml}$ ). (The TSH standard employed was calibrated against MRC TSH standard 68/38.) Antithyroglobulin antibodies were not detected in the serum. Serum proteins, calcium and inorganic phosphate were normal. Random urinary specific gravity ranged from 1.017 to $1 \cdot 024$. Serum growth hormone, prolactin, follicle stimulating hormone (FSH), luteinising hormone (LH), testosterone and cortisol as well as urinary 17-ketosteroids, and 17hydroxysteroids were all normal. Except for the measurement of serum $T_{3},{ }^{23}$ the methods for hormonal determinations have been described previously. ${ }^{24}$ 
Table Summary of cases of TSH-induced hyperthyroidism

\begin{tabular}{|c|c|c|c|c|c|}
\hline $\begin{array}{l}\text { Case } \\
\text { no }\end{array}$ & $\begin{array}{l}\text { Reference } \\
\text { no }\end{array}$ & $\begin{array}{l}\text { Age } \\
\text { (years) }\end{array}$ & $\operatorname{Sex}$ & $\begin{array}{l}\text { Approximate } \\
\text { duration of } \\
\text { thyrotoxicosis }\end{array}$ & Additional special features \\
\hline \multicolumn{6}{|c|}{ A. Patients with sellar enlargement } \\
\hline 1 & 1 & 51 & $\mathbf{F}$ & 4 months & Good response to radiotherapy. \\
\hline 2 & 2 & 51 & $\mathbf{F}$ & 3 years & Co-existent acromegaly and hyperthyroidism. \\
\hline 3 & 3 & 33 & $\mathbf{M}$ & 3 years & Elevated serum growth hormone. \\
\hline 4 & 4 & 50 & $\mathbf{M}$ & 3 years & Partial improvement after hypophysectomy. \\
\hline 5 & 5 & 25 & $\mathbf{M}$ & 5 years & \\
\hline 6 & 5 & 47 & $\mathbf{M}$ & 7 years & \\
\hline 7 & 6 & 21 & $\mathbf{F}$ & 3 years & Increased serum TSH after TRH stimulation. \\
\hline 8 & 7 & 40 & $\mathbf{F}$ & 1 year & No response of serum TSH to TRH. \\
\hline 9 & 8 & 53 & $\mathbf{F}$ & 1 year & Co-existent acromegaly. \\
\hline 10 & 9 & 25 & $\mathbf{M}$ & 5 years & Partial improvement after hypophysectomy. \\
\hline 11 & 10 & 22 & $\mathbf{F}$ & 6 years & Galactorrhea and hyperprolactinaemia. \\
\hline 12 & 11 & 23 & $\mathbf{M}$ & 2 years & $\begin{array}{l}\text { Hyperprolactinaemia and hypogonadism. } \\
\text { No response of serum TSH to TRH. }\end{array}$ \\
\hline 15 & 14 & 60 & $\mathbf{F}$ & 3 years & No response of serum TSH to TRH. \\
\hline 16 & 15 & 46 & $\mathbf{F}$ & 1 year & Co-existent acromegaly. No response of serum TSH to TRH. \\
\hline 17 & 16 & 57 & $\mathbf{M}$ & 2 years & No response of serum TSH to TRH. \\
\hline 18 & 17 & 45 & $\mathbf{M}$ & 10 years & No response of serum TSH to TRH. \\
\hline 19 & 18 & 20 & $\mathbf{F}$ & 8 months & No response of serum TSH to TRH. \\
\hline Presen & t Case & 31 & $\mathbf{M}$ & 7 months & $\begin{array}{l}\text { Exaggerated response of serum TSH to TRH. } \\
T_{3} \text { thyrotoxicosis. }\end{array}$ \\
\hline \multicolumn{6}{|c|}{ B. Patients without sellar enlargement } \\
\hline 20 & 19 & 44 & $\mathbf{F}$ & 3 years & No response of serum TSH to TRH stimulation. \\
\hline 21 & 20 & 18 & $\mathbf{F}$ & 11 years & Exaggerated response of serum TSH to TRH. \\
\hline 22 & 21 & 30 & $\mathbf{F}$ & 2 years & Exaggerated response of serum TSH to TRH. \\
\hline 23 & 12 (Case D) & 21 & $\mathbf{M}$ & 4 years & Exaggerated response of serum TSH to TRH. \\
\hline 24 & 12 (Case F) & 18 & $\mathbf{M}$ & 7 years & Exaggerated response of serum TSH to TRH. \\
\hline 25 & 22 & 11 & $\mathbf{M}$ & 7 years & Exaggerated response of serum TSH to TRH. \\
\hline
\end{tabular}

Skull radiography showed a markedly enlarged sella turcica with erosion of the dorsum sellae. Bilateral carotid arteriography showed unfolding and lateral displacement of the carotid siphons.

Treatment with methimazole, $30 \mathrm{mg}$ per day resulted within one month in a gradual fall in serum $\mathrm{T}_{4}$ and $\mathrm{T}_{3}$ levels and a concomitant rise in serum TSH levels. When the patient became euthyroid (serum $\mathbf{T}_{3}$ $2 \cdot 0 \mathrm{nmol} / \mathrm{l}$, serum $\left.T_{4} 64 \cdot 3 \mathrm{nmol} / \mathrm{l}\right)$, the intravenous administration of $400 \mu \mathrm{g}$ of thyrotropin-releasing hormone (TRH) resulted in a brisk rise in serum TSH levels, from a baseline of $600 \mu \mathrm{U} / \mathrm{ml}$ to $2600 \mu \mathrm{U} / \mathrm{ml}$ within 30 minutes. There was a minimal rise in serum prolactin.

Two weeks later, a hypophysectomy was performed through a sub-frontal approach. A large pituitary tumour weighing about $10 \mathrm{~g}$ was excised. Postoperatively, there was a rapid fall in serum TSH levels reaching $50 \mu \mathrm{U} / \mathrm{ml}$ in 24 hours and a normal level of $3.8 \mu \mathrm{U} / \mathrm{ml}$ by the twelfth post-operative day. On a regular monthly follow-up for the subsequent 32 months, the patient was asymptomatic and there was gradual and complete regression of the thyroid enlargement. Serial serum TSH determinations ranged from 4.5 to $6.5 \mu \mathrm{U} / \mathrm{ml}$, serum $\mathrm{T}_{4}$ from $79.8-95.2 \mathrm{nmol} / 1$ and serum $T_{3}$ from $1 \cdot 23-2 \cdot 0 \mathrm{nmol} / \mathrm{l}$. Visual field examination showed significant improvement in the previous defects. Repeat skull radiographs showed no further increase in sellar size. Adrenal and testicular functions continued to be normal. The patient was not given pituitary irradiation.

Histological examination of the tumour revealed the parenchymal component to consist primarily of sheets of angular polyhedral cells with a finely granular cytoplasm (fig, A). Several staining procedures were used on paraffin sections and all revealed intracellular granules with the staining characteristics of thyrotropes. ${ }^{25-27}$ Electron microscopic examination showed cells with many cytoplasmic granules varying in size between 100 and $200 \mathrm{~nm}$ in diameter, a feature characteristic of thyrotropes 28 (fig, B). TSH content of a $60 \mathrm{mg}$ portion of the tumour homogenised in $50 \mathrm{ml}$

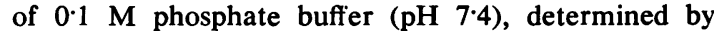
radioimmunoassay, was $2330 \mu \mathrm{U} / \mathrm{mg}$ of wet tissue. In the same homogenate, no detectable amounts of growth hormone, prolactin, LH or FSH could be found.

\section{Discussion}

It is well known that in the hyperthyroidism of Grave's disease, toxic nodular goitre or a toxic adenoma, serum TSH levels are usually suppressed, often to undetectable levels. The presence of elevated serum TSH levels in hyperthyroidism together with a pituitary tumour, suggests the rare condition of pituitary thyrotropin hypersecre- 


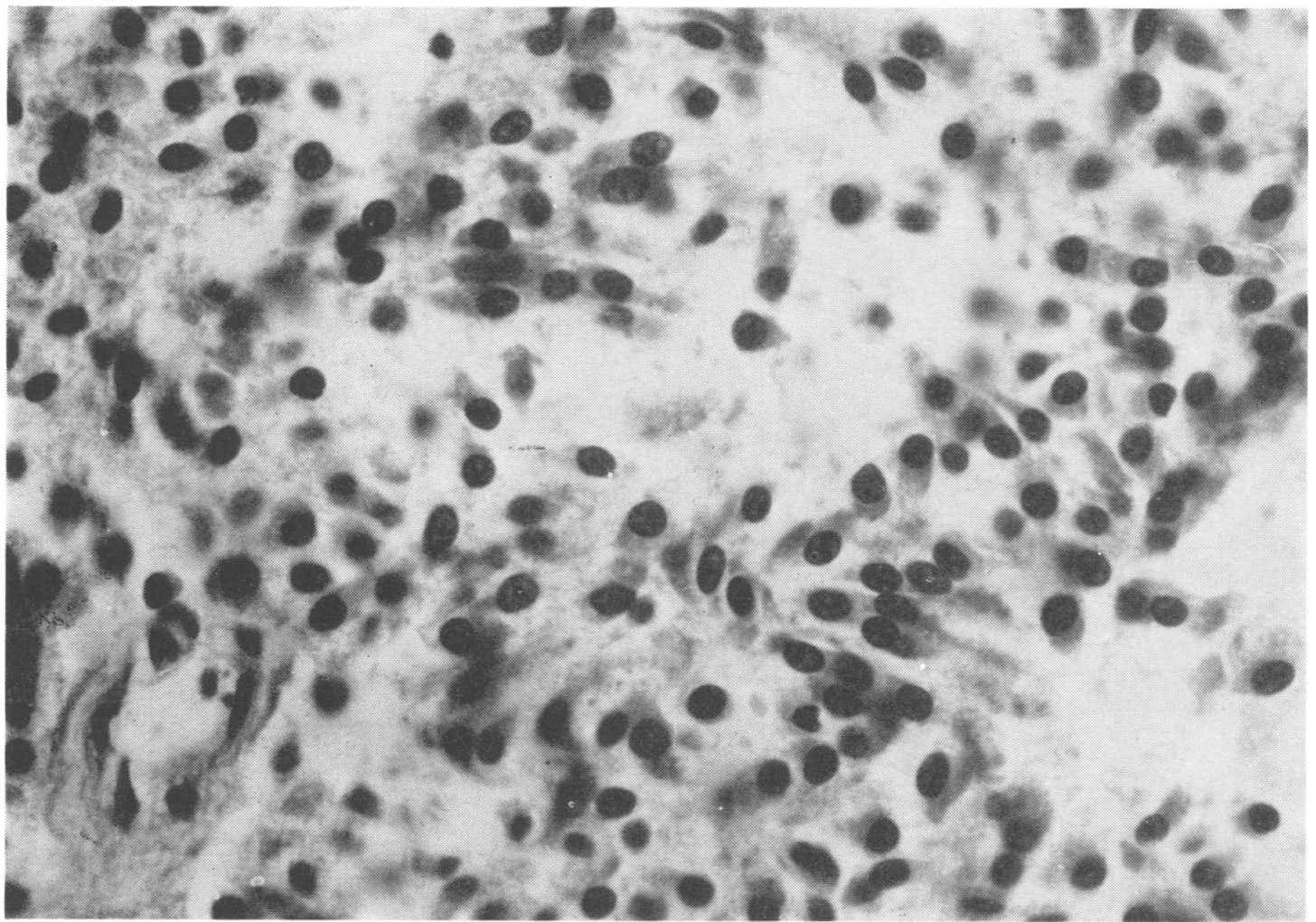

Figure (A) Photomicrograph of pituitary tumour showing angular polyhedral cells with finely granular cytoplasm. Magnification $\times 780$, aldehyde fuchsin counterstained with Ehrlich's hematoxylin.

tion as the cause of thyroid hyperfunction. In the patient described here, this possibility is substantiated by the prompt and sustained fall in serum TSH and amelioration of the thyroid enlargement and hyperthyroidism following the surgical removal of the tumour. Moreover, this patient had no exophthalmos or other stigmata of Graves' disease. The occurrence of pure $T_{3}$ thyrotoxicosis in this patient may have been related to the fact that he was living in an iodine-deficient area. ${ }^{29}$ However, an alternate explanation might be that excessive TSH stimulation results in a preferentially higher $T_{3}$ than $T_{4}$ secretion as shown by the fall of the serum $T_{3}$ over $T_{4}$ ratio after the hypophysectomy.

The previously reported 19 cases of TSHproducing tumours with hyperthyroidism are briefly summarised in the table. Unlike the usual female preponderance in the other common causes of hyperthyroidism, the female to male ratio in this group was only 10 to 9 . However, the age range was not different from that of the common causes of hyperthyroidism. The average duration of the thyrotoxic state until the time of diagnosis of TSH hypersecretion was approximately 3.3 years. It is possible that this relatively long duration reflects the fact that the specific diagnosis of TSH excess is often arrived at late because of the rare nature of this condition. Another interesting feature of TSH-producing tumours is the relatively high incidence of concomitant hypersecretion of growth hormone in five patients and prolactin in three others (table). While this observation might imply the occurrence of tumours of mixed cellular types, its pathogenesis remains unexplained. Its significance lies in that it makes the search for TSH excess, which could be occult, advisable in patients with acromegaly or prolactinomas.

The autonomy of TSH secretion in patients with TSH producing tumours appears to be variable. In the ten patients who were tested with intravenous TRH, only two responded with a rise in serum TSH while the other eight patients did not show any response. Antithyroid treatment, causing a fall of serum thyroid hormones to normal, resulted in a further rise in serum TSH in five 


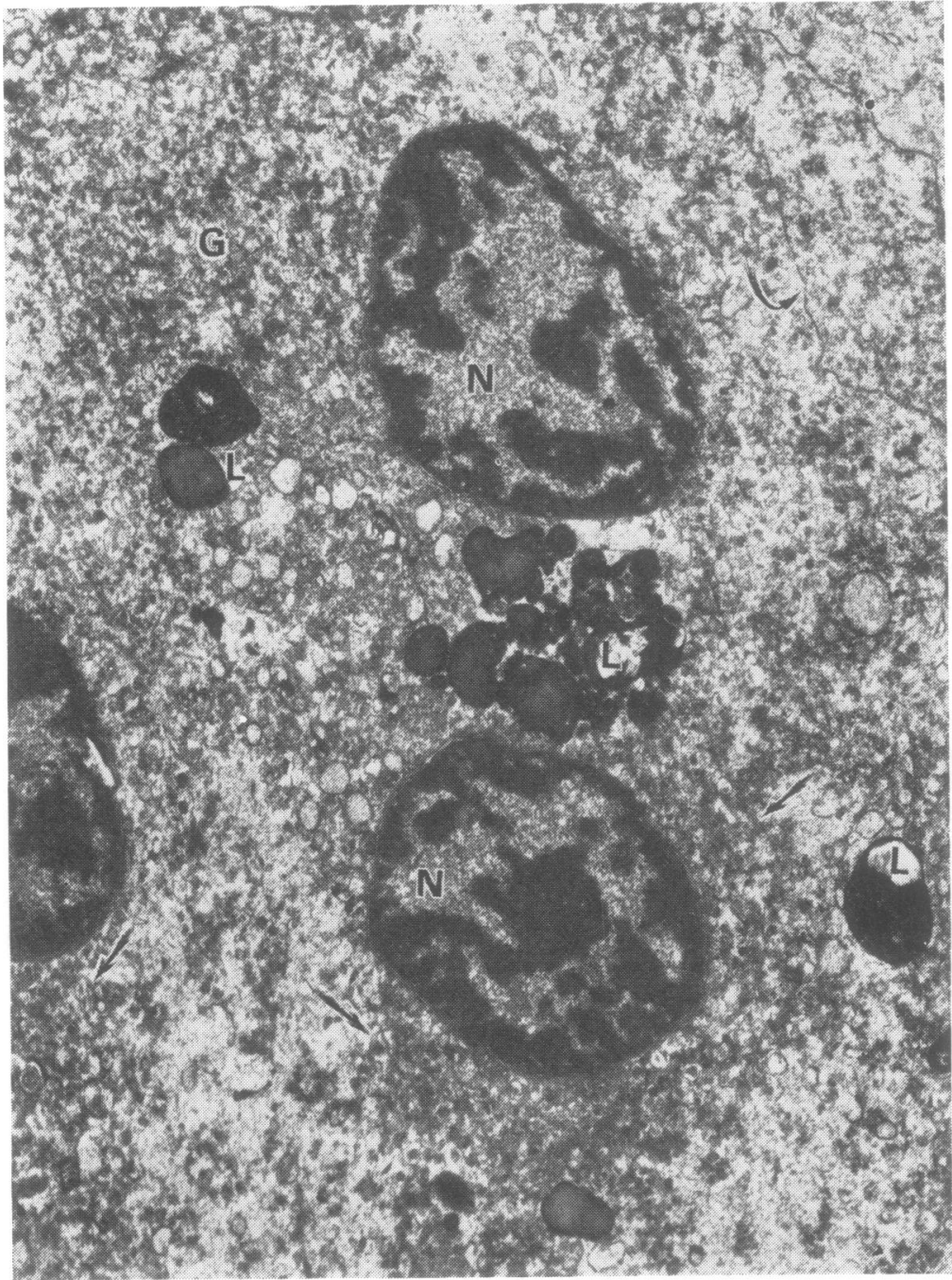

Figure (B) Electron micrograph showing portions of tumour cells. The nuclei $(N)$ contain dense clumped chromatin and a fine granular texture. The cytoplasm contains granules $(G)$ which are enveloped in membranes and appear to eminate in close relationship to the nucleus (straight arrows). Lipochrome pigment granules $(L)$ are also seen. The cell membrane is indicated by a curved arrow. Original magnification $\times 8800$. patients but not in two others. Thus it appears that at least a few of the tumours were not completely autonomous and responded to TRH administration or changes in circulating levels of thyroid hormones or both.

The six patients in whom no seilar enlargement was found (cases 20-25, table) may not necessarily comprise a homogeneous group. It is conceivable that some of them might have had small pituitary microadenomas which were too small to be detected by routine radiography of the skull. In two patients, the authors attributed the inappropriate TSH hypersection to a selective pituitary resistance to the suppressive effect of thyroid hormones. ${ }^{2021}$ Five out of the six patients had a brisk rise in serum TSH after TRH administration. Thus it appears that in this group of patients, TSH hypersecretion is relatively less autonomous than in the group with overt pituitary tumours. The same findings were reported by Kourides $e^{2}$ al $^{12}$ in their study of TSH sub-units in thyrotropin-induced hyperthyroidism.

\section{References}

1 Jailer JW, Holub DA. Remission of Graves' disease following radiotherapy of a pituitary neoplasm. Am J Med 1960; 28:497-500.

2 Lamberg BA, Ripatti J, Gordin A, Juustila H, Sivula A, Björkenste G. Chromophobe pituitary 
adenoma with acromegaly and TSH-induced hyperthyroidism associated with parathyroid adenoma. Acta Endocrinol (Kbh) 1969; 60:157-62.

3 Linguette $M$, Herlant $M$, Fossati P, May JP, Decoulx M, Fourlinnie JC. Adenome hypophysaire a cellules thyrotropes avec hyperthyrodie. Ann Endocrinol (Paris) 1969; 30:731-40.

4 Hamilton CR, Adams LC, Maloof F. Hyperthyroidism due to a thyrotropin producing chromophobe adenoma. $N$ Eng J Med 1970; 283: 1077-80.

5 Faglia G, Ferrari C, Neri V, Beck-Peccoz P, Ambros B, Valentine F. High plasma thyrotropin levels in two patients with pituitary tumour. Acta Endocrinol (Kbh) 1972; 69:649-58.

6 Mornex R, Tommasi M, Cure M, Farcot J, Orgiazzi J, Rousset B. Hyperthyroidie associée á un hypopituitarism au cours de l'évolution d'une tumeur hypophysaire sécrétant TSH. Ann Endocrinol (Paris) 1972; 33:390-6.

7 Hrubesh M, Bockel K, Voseberg H, Wagner $H$, Hauss WH. Hyperthyroeose durch TSH-produzierendes chromophobes hypophysenadenom. Verh Deutsh Ges Inn Med (Munich) 1972; 78: 1529-32.

8 Hamilton CR, Maloof F. Acromegaly and toxic goitre. Cure of hyperthyroidism and acromegaly by proton beam partial hypophysectomy. J Clin Endocrinol Metab 1972; 35:659-63.

9 O'Donnel J, Hadden DR, Weaver JA, Montgomery DA. Thyrotoxicosis recurring after surgical removal of a thyrotropin-secreting pituitary tumour. Proc Roy Soc Med 1973; 66:441-2.

10 Horn K, Erhardt F, Fahlbusch R, Pickardt CR, Werder KV, Scriba PC. Recurrent goitre, hyperthyroidism, galactorrhea and amenorrhoea due to a thyrotropin and prolactin producing tumour. $J$ Clin Endocrinol Metab 1976; 43:137-43.

11 Baylis PH. Case of hyperthyroidism due to a chromophobe adenoma. Clin Endocrinol 1976; 5:145-50.

12 Kourides IA, Rigeway EC, Weintraub BD, Bigos ST, Gershengorn MC, Maloof F. Thyrotropininduced hyperthyroidism: Use of alpha and beta subunit levels to identify patients with pituitary tumours. J Clin Endocrinol Metab 1977; 45: $534-43$.

13 Duello TM, Halmi NS. Pituitary adenoma producing thyrotropin and prolactin: An immunocytochemical and electron microscopic study. Virchows Archive 1977; 376:255-65.

14 Tolis G, Bird CE, Bertrand G, Mekenzie JM, Ezrin C. Pituitary hyperthyroidism: Case report and review of the literature. Am J Med 1977; 64:177-81.

15 Smallridge RC, Wartofsky L, Dimond RC. Inappropriate secretion of thyrotropin: Discordance between the suppressive effects of corticosteroids and thyroid hormones. J Clin Endocrinol Metab 1979; 48:700-5.

16 Waldhäust $\mathrm{W}$, Bratash-Marrain $\mathrm{P}$, Nowotny $\mathrm{P}$, et al. Secondary hyperthyroidism due to thyrotropin hypersecretion: Study of pituitary tumour morphology and thyrotropin chemistry and release. J Clin Endocrinol Metab 1979; 49:879-87.

17 Alfraisiabi A, Valenta L, Gwinup G. A TSH secreting pituitary tumour causing hyperthyroidism: Presentation of a case and review of the literature. Acta Endocrinol (Kbh) 1979; 92:44854.

18 Benoit R, Pearson-Murphy BE, Robert F, et al. Hyperthyroidism due to a pituitary TSH secreting tumour with amenorrhoea galactorrhoea. Clin Endocrinol 1980; 12:11-9.

19 Emerson $\mathrm{CH}$, Utiger RD. Hyperthyroidism and excessive thyrotropin secretion. $N$ Eng J Med 1972; 27:328-33.

20 Gershengorn MC, Weintraub BD. Thyrotropininduced hyperthyroidism caused by selective resistance to thyroid hormone: A new syndrome of "inappropriate secretion of TSH". J Clin Invest 1975; 56:633-42.

21 Elewant A, Mussche M, Vermeulen A. Familial partial organ resistance to thyroid hormone. $J$ Clin Endocrinol Metab 1976; 43:575-81.

22 Novogroder $\mathbf{M}$, Utiger $\mathbf{R}$, Boyar $\mathbf{R}$, Levine $\mathbf{L}$. Juvenile hyperthyroidism with elevated thyrotropin (TSH) and normal 24 hour FSH, LH, GH and prolactin secretory patterns. J Clin Endocrinol Metab 1977; 45:1053-9.

23 Hersch RD, Evered D. Radioimmunoassay of triiodothyronine in unextracted human serum. $\mathrm{Br}$ Med J 1965; 1:645-8.

24 Arafah B, Salti IS. Partial hypopituitarism following septic peritonitis with shock. Arch Int Med 1978; 138:1272-73.

25 Purves HA, Ginesback WE. The site of thyrotropin and gonadotropin production in the rat pituitary studied by McManus-Hatchkiss staining for glycoprotein. Endocrinology 1951; 49:244-64.

26 Emmel VM, Cowdry EV. Laboratory Technique in Biology and Medicine, Fourth Edition, Baltimore: Williams and Wilkins, 1964:7.

27 Halmi NS. Two types of basophils in the rat pituitary "thyrotrophs" and "gonadotrophs" vs beta and delta cells. Endocrinology 1952; 50:140-2.

28 Samaan NA, Osborne BM, Mckay B, Leavens ME, Duello TM, Halmi NS. Endocrine and morphologic studies of pituitary adenomas secondary to primary hypothyroidism. J Clin Endocrinol Metab 1977; 45:903-11.

29 Hollander CS, Stevenson C, Mitsuma T, Pineda G, Shenkman L, Silva E. $T_{3}$ toxicosis in an iodinedeficient area. Lancet 1972; 2:1276-8. 